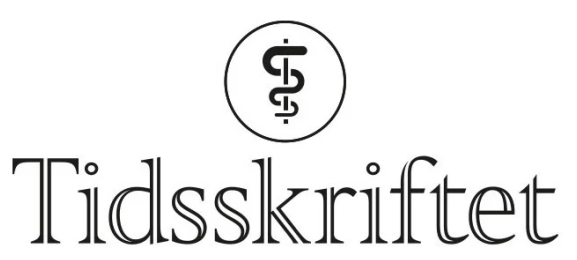

DEN NORSKE LEGEFORENING

\title{
Delirium hos pasienter med covid-19
}

DEBATT

\section{BJØRN ERIK NEERLAND}

bjorn.erik@neerland.net

Bjørn Erik Neerland er ph.d., spesialist i indremedisin og i geriatri, forsker og overlege ved Geriatrisk avdeling, Oslo universitetssykehus. Han er leder for Faggruppen for delirium i Norsk forening for geriatri.

Forfatteren har fylt ut ICMJE-skjemaet og oppgir ingen interessekonflikter.

\section{LEIV OTTO WATNE}

Leiv Otto Watne er ph.d., forsker og lege i spesialisering i indremedisin og i geriatri ved Geriatrisk avdeling, Oslo universitetssykehus. Han er leder for Oslo Delirium Research Group. Forfatteren har fylt ut ICMJE-skjemaet og oppgir ingen interessekonflikter.

\section{MARIA KROGSETH}

Maria Krogseth er ph.d, lege i spesialisering del 2 ved Medisinsk avdeling, Sykehuset i Telemark, forsker ved Alderspsykiatrisk forskningsnettverk Telemark og Vestfold og førsteamanuensis II ved Universitetet i Sørøst-Norge.

Forfatteren har fylt ut ICMJE-skjemaet og oppgir ingen interessekonflikter.

\section{Mange av pasientene med covid-19 vil utvikle delirium. Dette gir ekstra utfordringer for helsepersonell i en allerede krevende situasjon. Vi kommer her med noen konkrete råd om håndtering av delirium hos pasienter med covid-19.}

Delirium er et klinisk syndrom preget av akutt mental endring, oppmerksomhetssvikt og påvirket bevissthet (1). Forekomsten av delirium ved covid-19 er foreløpig ukjent, men det er ingen grunn til å tro at tallene er lavere enn for andre infeksjoner eller alvorlige sykdomsforløp. Delirium kan være et symptom på covid-19, og man bør derfor mistenke

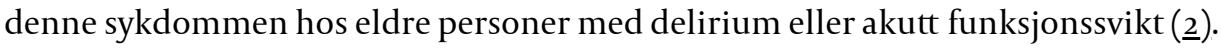
Adferdssymptomene man ofte ser ved delirium, slik som motorisk uro og agitasjon, kan gjøre behandlingen mer krevende og $ø$ ke risikoen for smittespredning.

Delirium sees hos over $20 \%$ av eldre pasienter innlagt i sykehus og hos over halvparten av pasientene i en intensivavdeling (3). De viktigste risikofaktorene er høy alder, kognitiv svikt, multisykelighet og sansesvikt. På sykehjem, der de fleste beboere har demens, vil svært mange utvikle delirium ved akutt sykdom (4). Alle pasienter kan, uavhengig av alder og komorbiditet, utvikle delirium ved alvorlig infeksjon og respirasjonssvikt (5).

\section{Kan gi store utfordringer}


Det er sterkt anbefalt å implementere ikke-medikamentelle tiltak i behandlingen av delirium, men dette kan bli krevende i en situasjon med mange covid-19-pasienter. Smitteisolering og personell i smittevernutstyr vil kunne øke uro, angst og vrangforestillinger hos en allerede redd og kognitivt påvirket pasient. Pasienter med delirium samarbeider ofte dårligere om medisinsk behandling, tar til seg mindre mat og drikke og har høy risiko for fall. Dessuten vil pasienter med delirium ofte ha problemer med å forstå smitteverntiltak. Det kan fort bli for ressurskrevende med fastvakt for å forhindre at pasienten forlater rommet eller avdelingen.

I visse situasjoner kan det være gunstig fra et smittevernsynspunkt å ha en pårørende til stede som kan roe pasienten og hindre ham/henne i å vandre omkring. Helsedirektoratets retningslinjer for besøksforbud åpner opp for unntak, eksempelvis når pasienten er kritisk syk. Ved unntak må helseinstitusjonen i hvert enkelt tilfelle strengt vurdere betydningen av besøket opp mot risiko for smitte( $\underline{6})$.

«Alle pasienter kan, uavhengig av alder og komorbiditet, utvikle delirium ved alvorlig infeksjon og respirasjonssvikt»

Så langt det lar seg gjøre bør forebyggende tiltak og ikke-medikamentell behandling iverksettes som ellers. Legemidler som kan utløse, forverre eller vedlikeholde delirium, må seponeres eller pauses. I noen situasjoner kan det grunnet smittefare bli aktuelt med medikamentell håndtering på et tidligere stadium og med større doser enn det som ellers er anbefalt. De grunnleggende prinsippene for behandling av pasienter med manglende samtykkekompetanse gjelder som ellers. Bruk av tvang i somatisk behandling av pasienter med manglende samtykkekompetanse er regulert i helsepersonelloven $\S 7$ og i pasient- og brukerrettighetsloven kapittel $4 \mathrm{~A}$.

\section{Våre anbefalinger}

Anbefalingene våre må oppfattes veiledende og benyttes sammen med lokale prosedyrer og rutiner. Vårt oppsett er inspirert av tilsvarende anbefalinger publisert av British Geriatrics Society (7.). Forfatterne av de britiske retningslinjene har gitt oss tillatelse til å bygge vår versjon på deres oppsett. Anbefalingene våre er ingen direkte oversettelse, men er betydelig bearbeidet og tilpasset den aktuelle covid-19-situasjonen i Norge.

\section{SCREENING FOR DELIRIUM}

Vi anbefaler screening for delirium hos risikopasienter, for eksempel 70 år og eldre, med bruk av verktøyet 4AT www.the4AT.com) (( $\underline{8})$. I samtale med pårørende bør man kartlegge pasientens kognitive funksjon to uker før akutt sykdom. Dette kan med fordel fremkomme i et eventuelt henvisningsskriv.

Reduser risiko for delirium, så langt det lar seg gjøre, ved å reorientere pasienten hyppig, skape trygghet og ro, mobilisere, korrigere sansesvikt, forebygge dehydrering, obstipasjon og urinretensjon, behandle smerter, tidlig identifisere og behandle superinfeksjoner, sikre oksygenering og å gå grundig gjennom medikamentlisten (9.).

Ved etablert delirium må man identifisere og behandle de utløsende årsakene, som i tillegg til covid-19 kan være blant annet smerte, urinretensjon, hypoksemi, dehydrering eller annen infeksjon.

\section{ANTIPSYKOTIKA}

Dersom dette ikke er tilstrekkelig, og rask kontroll på adferdssymptomer er vesentlig for å forhindre skade (smitte) på andre personer, kan medikamentell symptomlindrende behandling være aktuelt på et tidligere tidspunkt enn normalt anbefalt. Antipsykotika er 
ikke anbefalt brukt rutinemessig ved delirium, men dersom pasienten er veldig plaget med vrangforestillinger og hallusinasjoner eller er i fare for å skade seg selv eller andre, kan det overveies i forsiktig opptrappende doser.

Haloperidol har spesifikt dempende effekt på psykotiske symptomer og anses som førstevalg. Aktuell dosering er o,5-1 mg peroralt eller intramuskulært hvert 3o. minutt inntil ønsket effekt. Døgndoser høyere enn 5 mg bør unngås.

Som vanlig må antipsykotika brukes med særlig forsiktighet hos personer med Parkinsons sykdom eller demens med lewylegemer.

\section{ANNEN MEDIKAMENTELL BEHANDLING}

Benzodiazepiner bør som hovedregel unngås ved behandling av delirium. Dette gjelder særlig covid-19-pasienter, fordi medikamentene har respirasjonsdempende effekt.

Dersom pasienten er smittefarlig og man må kontrollere situasjonen med sedasjon, eller pasienten er veldig angstpreget, er midazolam $\left(0,5^{-1}\right.$ mg subkutant eller intravenøst inntil hvert 3o. minutt) å foretrekke framfor for eksempel diazepam, grunnet betydelig kortere halveringstid. Pasienten må ikke sederes for dypt.

Klometiazol anses kontraindisert ved akutt svekket lungefunksjon og $ø$ kt bronkial sekresjon.

Klonidin har angstdempende og lett sedativ effekt, og $75 \mu g$ gitt peroralt to ganger i døgnet, opp til $150 \mu g \times 3$, kan vurderes for pasienter uten uttalt kardiovaskulær sykdom, bradykardi eller hypotensjon (므).

På intensivavdeling er deksmedetomidin førstevalg.

\section{MONITORERING}

Pasienter som er gitt antipsykotisk eller sederende behandling må monitoreres hyppig med tanke på bivirkninger, bevissthetsnivå og øvrige vitalia. Antidot (flumazenil) må være tilgjengelig. Hyppighet av observasjonene må veies opp mot smitterisiko og ressursbruk knyttet til å undersøke pasienter i smitteisolat.

Takk til Geir Selbcek, Torgeir Bruun Wyller samt Faggruppe for delirium, Norsk geriatrisk forening ved Sigurd Evensen, Yngve Müller Seljeseth, Heidi Sandvig, Marc Vali Ahmed, Paal Naalsund, Tone Hagerup og Vegard Vevatne for gjennomlesning av manus og nyttige bidrag til innholdet.

\section{LITTERATUR}

1. Neerland BE, Watne LO, Wyller TB. Delirium hos eldre pasienter. Tidsskr Nor Legeforen 2013; 133: 1596-6oo. [PubMed][CrossRef]

2. Myrstad M, Ranhoff AH. Akutt syke eldre i koronaens tid. Tidsskr Nor Legeforen 2020; 140. doi: 10.4045/tidsskr.20.0227. [CrossRef]

3. Marcantonio ER. Delirium in hospitalized older adults. N Engl J Med 2017;377: 1456-66. [PubMed] [CrossRef]

4. Boockvar K, Signor D, Ramaswamy R et al. Delirium during acute illness in nursing home residents. J Am Med Dir Assoc 2013; 14: 656-6o. [PubMed][CrossRef]

5. Hsieh SJ, Soto GJ, Hope AA et al. The association between acute respiratory distress syndrome, delirium, and in-hospital mortality in intensive care unit patients. Am J Respir Crit Care Med 2015; 191: 71-8. [PubMed][CrossRef]

6. Helsedirektoratet. Smittevern for pasienter og befolkning.

https://www.helsedirektoratet.no/veiledere/koronavirus/smittevern-for-pasienter?

malgruppe=undefined\#alle-helseinstitusjoner-skal-innfore-adgangskontroll-for-besokende Lest 25.3.2020

7. British Geriatrics Society. Coronavirus: Managing delirium in confirmed and suspected cases https://www.bgs.org.uk/resources/coronavirus-managing-delirium-in-confirmed-and-suspected-cases Lest 30.3.2020. 
8. Evensen S, Forr T, Al-Fattal A et al. Nytt verktøy for å oppdage delirium og kognitiv svikt. Tidsskr Nor Legeforen 2016; 136: 299-300. [PubMed][CrossRef]

9. Helsebiblioteket. Delirium - forebygging, diagnostikk og behandling.

https://www.helsebiblioteket.no/fagprosedyrer/ferdige/delirium-diagnostikk-og-behandling Lest 24.3.2020.

10. Hov KR, Neerland BE, Andersen AM et al. The use of clonidine in elderly patients with delirium; pharmacokinetics and hemodynamic responses. BMC Pharmacol Toxicol 2018; 19: 29. [PubMed] [CrossRef]

Publisert:3. april 2020. Tidsskr Nor Legeforen. DOI: 10.4045/tidsskr.20.0264

Mottatt 26.3.2020, første revisjon innsendt 31.3.2020, godkjent 31.3.2020.

(C) Tidsskrift for Den norske legeforening 2023. Lastet ned fra tidsskriftet.no 26. april 2023. 